\title{
O conto fantástico na formação do leitor: uma leitura do conto "O buraco", de Luiz Vilela
}

\author{
The fantastic narrative in the reader's formation: a Reading of the tale "O buraco", By Luiz Vilela
}

\section{Eliane Aparecida Galvão Ribeiro Ferreira}

Universidade Estadual Paulista "Júlio de Mesquita Filho" - UNESP - São Paulo - Brasil

Ricardo Magalhães Bulhões

Universidade Federal de Mato Grosso do Sul - UFMS - Três Lagoas - Brasil

\begin{abstract}
Resumo: Objetiva-se, neste texto, apresentar uma reflexão sobre a narrativa fantástica e suas potencialidades para a formação do leitor. Para a consecução desse objetivo, elegeu-se para análise o conto "O buraco", do escritor Luiz Junqueira Vilela (2016, p.1938), pinçado de sua coletânea Três histórias fantásticas (2016), a qual compõe os acervos de 2011 do PNBE - Programa Nacional Biblioteca na Escola, destinados aos jovens do Ensino Médio. Pretende-se problematizar, na análise desse conto, a configuração em sua narrativa do leitor implícito, a partir das contribuições teóricas da Estética da Recepção e do Efeito (JAUSS, 1994; ISER, 1996 e 1999). Justifica-se esse aporte teórico, pois as obras destinadas ao público juvenil buscam explicitamente a recepção. Além disso, essa abordagem permite observar se esse conto, escrito no final de década de 1960, possui vitalidade para cativar o jovem leitor, pois mantém comunicabilidade na leitura e promove sua reflexão crítica, por meio do rompimento de seus conceitos prévios e da ampliação de seus horizontes de expectativas.
\end{abstract}

Palavras-chave: Conto fantástico. Estética da Recepção e do Efeito. Formação do Leitor.

\begin{abstract}
The aim of this paper is to present a reflection on the fantastic narrative and its potential for the reader's formation. In order to achieve this goal, the tale "O Buraco", written by Luiz Junqueira Vilela (2016, p.19-38), chosen from his collection Três Histórias Fantásticas (2016), which takes part of the collections of 2011 of PNBE - Programa Nacional Biblioteca na Escola, aimed at high school youth. It is intended to problematize, in its analysis of this tale, the configuration in its narrative of the implicit reader, from the theoretical contributions of Reception and Effect Aesthetics (JAUSS, 1994; ISER, 1996 and 1999). This theoretical contribution is justified, since the works intended for the juvenile public explicitly reception. Furthermore, this approach allows us to observe whether this short story, written in the late 1960s, has the vitality to captivate the young reader, as it maintains communicability in reading and promotes critical reflection through the breaking of his previous concepts and the expansion his/her expectations horizons.
\end{abstract}

Keywords: Fantastic tale. Reception and Effect Aesthetics. Reader formation. 


\section{Introdução}

Este texto tem por objetivo apresentar uma reflexão sobre a narrativa fantástica e suas potencialidades para a formação do leitor. Para tanto, elegeu-se como objeto de estudo a coletânea Três Histórias Fantásticas, do escritor mineiro Luiz Junqueira Vilela (2016), composta pelos contos "Imagem" (p.7-18), "O buraco" (p.19-38) e "O fantasma" (p.39-51). A escolha dessa coletânea foi motivada pelo seu reconhecimento no campo da crítica literária, com a classificação "Altamente Recomendável", concedida pela FNLIJ - Fundação Nacional do Livro Infantil e Juvenil, em 2010 (FNLIJ, 2019). Também, pelo fato de compor os acervos de 2011 do PNBE - Programa Nacional Biblioteca na Escola, destinados aos jovens do Ensino Médio (PORTAL MEC, 2018). Embora esse Programa tenha sido suspenso em 2015 (FERNANDES, 2019), seus acervos permanecem disponíveis à leitura de jovens e mediadores, pois integram Salas de Leitura ou bibliotecas de escolas da rede pública do país.

Pela brevidade que este artigo exige, optou-se por analisar da coletânea de Vilela (2016) somente o conto "O buraco" (p.19-38), problematizando, a partir do aporte teórico da Estética da Recepção e do Efeito (JAUSS, 1994; ISER, 1996 e 1999), a configuração em sua narrativa do leitor implícito. Este leitor, embora seja uma projeção da estrutura de apelo do texto, revela o trânsito do âmbito ficcional ao social - da literatura para a experiência -, pois ocupa um lugar que vem a ser preenchido por um indivíduo real: o leitor empírico, no caso, o jovem leitor. Em síntese, visa-se observar qual é o efeito, na acepção de Hans Robert Jauss (1994), desse conto na leitura, se amplia ou não, por apresentar acontecimentos insólitos em seu enredo, os horizontes de expectativa desse leitor, além de conferir-Ihe prazer.

A eleição do aporte teórico da Estética da Recepção e do Efeito (JAUSS, 1994; ISER, 1996 e 1999) deve-se tanto à configuração da edição da coletânea de Vilela (2016) que, voltada ao público juvenil, visa à recepção; quanto à possibilidade de observar a vitalidade de seu conto "O buraco" (p.1938), pela capacidade de atrair esse público leitor e despertar seu senso crítico, ampliando, assim, seu horizonte de expectativa. Além disso, essa abordagem se justifica, pois, conforme Marcello de O. Pinto (2015, p.168), há "[...] quase total ausência de estudos sobre os efeitos desta literatura [fantástica] (inclusive no cerne de alguns projetos que se orientam para 0 potencial pedagógico desses textos [...])."

A ampliação do horizonte de expectativa, conforme Jauss (1994), decorre da distância estética que avulta na leitura, por meio da negação do horizonte conhecido ou preexistente - conceito prévio - da experiência estética anterior, que a obra nova exige para ser acolhida. Justamente, essa é a função social da leitura para o estudioso (1994), pois ao promover frustrações de expectativas, assegura 0 avanço da ciência e da experiência de vida. Quanto ao prazer na leitura, segundo Iser (1999), advém da estrutura de comunicação subjacente aos vazios presentes em um texto, os quais indicam os locais de entrada do leitor no universo ficcional. Assim, um texto, em sua estrutura de apelo, para sua feitura e acabamento, supõe um recebedor - leitor implícito - incumbido do preenchimento desses vazios. Por sua vez, a comunicação ocorre quando esse leitor, na busca do sentido, da concretude, procura resgatar a coerência do texto que os vazios interromperam. Esse resgate realizado pelo leitor é decorrente da utilização de sua atividade imaginativa.

Vale destacar que para Iser, "[...] a concepção de leitor implícito enfatiza as estruturas de efeitos do texto, cujos atos de apreensão relacionam o receptor a ele" (1996, p.73). Assim, a interação do leitor com o texto é obtida pelos espaços lacunares que, habilmente, a voz narradora produz. Como se pode notar, o leitor implícito difere do narratário, pois não se instaura na diegese, como personagem. Esse leitor é previsto na estrutura textual. Para Todorov, em Introdução à literatura fantástica, o leitor implícito é uma função de leitor que se inscreve no texto, e avulta na narrativa fantástica, pois esta "[...] define-se pela percepção ambígua que o próprio leitor tem dos acontecimentos relatados" (1981, p.19), ou seja, ele se vê diante de um dilema: "[...] acreditar ou não acreditar?" (1981, p.45). Para o estudioso, a "[...] 
vacilação do leitor é pois a primeira condição do fantástico" (TODOROV, 1981, p.19). Justamente, essa ambiguidade instaura vazios no texto que suscitam a produtividade na leitura. A presença de vazios intencionais em um texto fantástico - resultantes do elemento insólito, de silenciamentos, potências de negação, reticências, ambiguidades, entre outros -, gera suspense, o qual, por sua vez, explora a curiosidade do leitor que não consegue parar de ler até o desfecho da história.

De acordo com Todorov (1981), o fantástico, que decorre de acontecimentos estranhos, exerce três funções em um texto. A primeira função é a de produzir sobre o leitor efeitos de comoção, assombro, "[...] medo, horror ou simplesmente curiosidade" (TODOROV, 1981, p.50); a segunda instaura-se na narração, na manutenção do suspense que avulta de uma organização "[...] rodeada da intriga" (p.50); e a terceira advém dos aspectos semânticos, dos temas eleitos. $\mathrm{Na}$ narrativa fantástica, é fulcral o questionamento do "[...] limite entre o real e o irreal" (TODOROV, 1981, p.87).

David Roas (2014) concorda com Todorov sobre ser fundamental a participação ativa do leitor para a existência do fantástico. Contudo, discorda que a vacilação do leitor seja aceita como condição primeira do gênero, em especial, quando se contempla a narrativa contemporânea, "[...] inserida na visão pósmoderna da realidade, segundo a qual o mundo é uma entidade indecifrável" (ROAS, 2014, p.66).

Como se pode notar, a categorização do fantástico é complexa e, ao longo da história, conforme Karin Volobuef (2000), pautando-se em Coalla (1994), atravessou diferentes fases, bem como utilizou-se de expedientes diversos para criar a hesitação. Assim, o fantástico, no final do século XVIII e início do XIX, exigia a presença do sobrenatural, configurado em monstros e fantasmas, com a finalidade de produzir medo. Desse modo, a angústia era provocada por um elemento externo ao homem. No século XIX, o fantástico explora a dimensão psicológica - interna -, advinda de alucinações, pesadelos e loucura. No século $X X$, o fantástico instaura-se no plano da linguagem, por meio dela cria-se a incoerência e o absurdo. Para Volobuef (2000, p.111), "Se antes o insólito era produzido no nível semântico, no século XX ele se infiltra no nível sintático".

Por causa das peculiaridades do fantástico, a partir do século XX, textos, como os de Kafka, escapam das classificações de Todorov (1981), inclusive, sobre a hesitação do leitor. Uma vez que o insólito, muitas vezes, instaura-se já no início da narrativa. Além disso, a produção literária desse escritor congrega, segundo Voluebuf (2000), tanto traços do gênero estranho - em que a hesitação é instaurada, mas desfeita com explicações racionais -, quanto do maravilhoso - em que o sobrenatural é naturalizado.

De acordo com Marisa M. Gama-Khalil (2013), a hesitação do leitor, é um critério importante de definição do texto fantástico, contudo, há também a hesitação da personagem. Como recurso da narrativa fantástica, Yves Stalloni acrescenta a utilização do medo, pela presença do sobrenatural "[...] tanto mais impressionante porque ocorre num universo realista e verossímil, pela importância determinante do tema da hesitação, primeiro a da personagem e depois também a do leitor [...]" (2010, p.109). Para David Roas (2014), o efeito de vacilação provém de narrativas que, embora ambientadas em um mundo reconhecível pelo leitor, apresentam o insólito em seu enredo.

Nessas narrativas, o efeito do fantástico desdobra-se internamente - no plano da diegese - e externamente, no da estrutura do texto, a qual projeta um receptor. A relação dialógica entre texto e leitor instaura-se na estrutura textual, por meio de vazios, os quais promovem condições de comunicação. A interação na leitura, por sua vez, acontece pelo preenchimento desses vazios, em busca de interpretação - concretude -, via projeção imagética, construção e revisão de hipóteses (ISER, 1996). Para que a interação entre texto e leitor resulte em interpretação, de acordo com Iser (1996 e 1999), fazse necessário que o leitor, durante a leitura, projete expectativa e memória - uma sobre a outra -, a fim de verificar a validade de suas hipóteses e produzir sínteses. Por meio desse processo, pode-se atualizar 
e modificar o objeto, desenvolvendo novas expectativas.

O enredo do conto "O buraco" (VILELA, 2016, p.19-38) deixa evidente a intenção do contista mineiro de ofertar um relato surpreendente que, associado ao insólito e à temática identitária, cative seu provável receptor pela curiosidade, pelo suspense, pela hesitação e identificação. Em especial, o conto possui potencialidades para atrair o público jovem que, como o protagonista, se encontra também em fase de questionamentos sobre sua identidade.

Com produção inserida no boom do conto brasileiro em 1970, cujo salto qualitativo já ocorrera na década de 1960, Luiz Vilela chamou a atenção da crítica. Alfredo Bosi (2008, p.17) classificou-o como herdeiro da ficção mineira, em cuja prosa, mais arejada que a de Autran Dourado e Otto Lara Resende, prevalece a memória repleta de espantos e a "[...] fala coloquial". Para Ítalo Moriconi, Vilela é "[...] descendente legítimo das gerações de Carlos Drummond de Andrade, Fernando Sabino e Otto Lara Resende" (2001, p.282). Sua produção é tributária da estética modernista.

No contexto das décadas de 1960 e 1970, de consolidação do capitalismo tardio, conforme Renato Ortiz (2001), produzido por um Estado autoritário; de opressão política e social; resistência e dilaceramentos, os textos de Vilela opõem-se à euforia do consumo proveniente da classe média e da internacionalização, configurando sua escrita como denúncia do lado obscuro da realidade. Entre esses textos, situa-se o conto "O buraco" (2016, p.19-38) que, em sua origem, compôs o livro de estreia do autor, intitulado Tremor de terra, publicado em 1967. Este livro, ao ser contemplado com o Prêmio Nacional de Ficção, tornou Vilela conhecido em âmbito nacional (BOSI, 1985).

Constrói-se neste texto, então, a hipótese de que o conto "O buraco" (VILELA, 2016, p.19-38) estruturado sobre o insólito e a tensão do narrador, com suas paradoxais experiências - revela-se como metáfora desse momento histórico, social e político. Nossa hipótese justifica-se, pois Alfredo Bosi (1985, p.440), a partir dos pressupostos de Lucien Goldmann para uma abordagem genético-estrutural do romance, trata justamente da "[...] existência de homologias entre a estrutura da obra literária e a estrutura social, e, mesmo, grupal, em que se insere o seu autor." Essas homologias, em sua manifestação por meio da arte, apresentam-se sob a forma tensão, ou seja, do "[...] relacionamento do autor com o mundo objetivo, de que depende, e com o mundo estético, que lhe é dado construir" (BOSI, 1985, p.441). Nessa categoria, o crítico inclui os romances de 1930, classificando-os como de tensão crítica, interiorizada e transfigurada. Desta última, em que o herói busca "[...] ultrapassar o conflito que o constitui essencialmente" (BOSI, 1985, p.442), pode-se aproximar o conto de Vilela (2016), pois seu protagonista almeja superar sua condição existencial, por meio da transmutação mítica ou metafísica da realidade.

Parte-se do pressuposto, em consonância com David Roas (2014), de que o texto fantástico contemporâneo, o qual se constitui-se pela "[...] irrupção do anormal em um mundo aparentemente normal", faculta a formação e emancipação do jovem leitor, pois suscita reflexões sobre o incognoscível, a realidade e mesmo os limites da própria linguagem em apreender a subjetividade. A leitura da narrativa fantástica, embora apresente o sobrenatural, rompe com as produções culturais contemporâneas, repletas de zumbis, vampiros, lobisomens, entre outros, voltadas para o escapismo, produzindo a incerteza sobre a aparente coerência do mundo em que se vive.

\section{Adentrando o buraco}

No conto "O buraco" (VILELA, 2016, p.19-38), o que sobressai na trama é a construção de um ambiente insólito, surpreendente, completado pela imaginação do leitor que acompanha a saga de um jovem narrador, o qual relata em primeira pessoa suas ações de escavar, desde a infância, um buraco sem fim. Há, nesse texto de Vilela, uma desmedida simbologia: o protagonista, aos poucos, deixa-se seduzir pelo buraco que escava, a ponto de só se sentir bem em seu interior. Esse processo remete à dualidade "criador e criatura", em que o primeiro - o 
narrador -, ao escavar um buraco que aumenta e ganha profundidade na proporção de seu próprio crescimento, animaliza-se, optando por viver no subsolo, pois não consegue mais integrar-se aos sujeitos de seu convívio, que vivem na superfície. Pode-se perceber, então, que esse protagonista, durante o relato, torna-se símile de seu autor, pois também em seu relacionamento com o mundo objetivo precisa, pela inadequação, construir outro para si.

Como em $A$ metamorfose, de Franz Kafka, o fantástico instaura-se logo na abertura do relato. No conto de Vilela (2016), entretanto, há um aumento gradual da tensão. Assim, na mesma proporção em que cresce "o buraco", acentua-se o conflito existencial do narrador-personagem. A existência desse buraco e de seu aumento gradativo, por gerarem expectativa e assombro, podem enredar o leitor, atraí-lo para o interior desse espaço ao lado do protagonista, mantendo-o cativo à história. Já no primeiro parágrafo, o leitor implícito se depara com a percepção ambígua dos acontecimentos. Assim, o narrador-personagem coloca em xeque o início da escavação do buraco:

Não sei como nem quando começou o buraco. A lembrança mais antiga que eu tenho de mim coincide com a mais antiga que eu tenho dele: eu cavando-o com os dedos. Mas então ele já existia, e não sei se era eu que o havia começado ou outra pessoa. Ou, talvez, ele estivesse ali por simples acidente da natureza (VILELA, 2016, p.21).

Nota-se que, no relato pretérito do narrador, a ambiguidade decorre de suas dúvidas. Seu discurso, marcado pela potência de negação - "Não sei como nem quando [...]" (VILELA, 2016, p.21) - produz efeito de hesitação. Desse modo, rompe com os conceitos prévios do leitor em formação sobre relatos ulteriores, em geral, dotados de um narrador que se configura como profundo conhecedor dos rumos da história. Além disso, nota-se que o protagonista, bem como o que ele descreve - o "buraco" -, coincidem em suas memórias; ambos aparecem juntos. O "buraco" está na origem das lembranças do narrador, embora este não saiba se ele já existia como acidente da natureza ou se fora feito por outra pessoa, ou se o criara.
Nos parágrafos seguintes, o leitor passa a acompanhar o crescimento de ambos. Aos três anos de idade, surgem os primeiros momentos de isolamento do protagonista que permanece cavando o buraco, como quem se dedica a um brinquedo. Aos quatro e cinco anos, cava por falta de opção ou tédio, ou desejo de fazê-lo. Com o seu crescimento, entre seis e dez anos, o buraco começa a assumir forma arredondada em um anúncio do refúgio que viria a ser. Apesar de situar-se no quintal de sua casa, ser visto pelos que ali passam - e o protagonista ainda não têlo adentrado em seu espaço paradoxal, marcado pelo vazio -, ele o concebe como privado e secreto. Notase, então, que a definição do buraco, bem como sua localização, rompem com as relações de causalidade e finalidade, produzindo a transgressão linguística em todos os níveis do texto: semântico, sintático e de discurso, como negação da transparência da linguagem.

Sua mãe o observa e apresenta comportamento, bem como discurso, ambíguos:

Às vezes Mamãe me via cavando-o e dizia: "Meu filho, deixa esse brinquedo, vai brincar na rua com os outros meninos". Mas às vezes também via e não dizia nada, não se importava, e, de certo modo, até parecia achar bom: "Assim, ele não vai para longe", dizia aos outros (VILELA, 2016, p.22).

Pode-se observar que a mãe do narrador ora o repreende, desejando que brinque com outras crianças, ora aceita seu comportamento, justificando que aprecia sua proximidade. Vale destacar que a aceitação da mãe, manifesta em suas justificativas sobre as atitudes do filho, também pode instaurar o estranhamento para o leitor habituado com histórias em que as progenitoras aconselham e guiam seus rebentos à socialização, desejada pelo consenso social.

Aos onze anos, o protagonista não sabe o que o motiva a cavar e afirma que "Talvez fosse apenas por hábito" (VILELA, 2016, p.23). Percebe-se no relato o hesitar do narrador, pelo instaurar da dúvida manifesta no emprego do advérbio "talvez". Embora até essa idade não apareça de forma explícita no discurso do 
narrador o conflito da inadequação ao mundo, acontece algo inexplicável que o amedronta:

Uma vez aconteceu uma coisa estranha: eu tive como que uma visão de algo pavoroso surgindo do buraco, e saí correndo feito doido para dentro de casa. Mas, depois, eu não conseguia saber o que me dera tanto medo, não consegui ter nenhuma imagem. Mesmo assim, foi uma sensação tão horrível, que eu fiquei algum tempo sem voltar lá (VILELA, 2016, p.23).

Desse modo, acentua-se um acontecimento insólito que, marcado pela impossibilidade de definição e descrição, promove o pavor no narrador. Esse efeito é obtido pela comparação hiperbólica "[...] saí correndo feito doido" (VILELA, 2016, p.23 - grifos nossos); pela afirmação do "medo", proveniente de uma "sensação horrível" e da "visão de algo pavoroso"; e pela dupla negação que instaura um vazio, um "buraco" no relato: "[...] eu não conseguia saber o que me dera tanto medo, não consegui ter nenhuma imagem" (2016, p.23 - grifos nossos).

A hesitação para o leitor, bem como a manutenção do suspense, advêm da ausência de descrição - elipse - sobre o que provoca medo e desconforto no narrador. Essa estética da elipse, aliada à da simplicidade, define, conforme Flávio Carneiro (2005), a obra de Vilela. A maestria do escritor revela-se na comunicabilidade, poi pois, ao sugerir, com poucas palavras, cenários, personagens e enredos, deixa lacunas que precisam ser completadas pela imaginação do leitor. Por sua vez, o efeito de estranhamento aumenta pela presença do sobrenatural, insólito, em um cenário mundano, composto por uma casa modesta, em que residem mãe e filho, com um quintal de terra, situada em uma pequena cidade do interior, em que todos se conhecem.

Ao completar quinze anos, o narrador adquire outra percepção sobre o buraco:

E então foi como se, de repente, eu o visse pela primeira vez - como se ele nunca tivesse existido antes desse dia, [...]. Foi uma sensação empolgante, mas também assustadora; fiquei maravilhado e, ao mesmo tempo, com medo. Na manhã desse dia eu estava alegre; mas, de tarde, não sabia se estava alegre ou triste; e de noite estava triste. De qualquer modo, uma coisa era certa: aquele buraco existia e era meu, inseparavelmente meu, tão meu que era como se ele estivesse não ali, fora, mas dentro de mim. Eu podia ignorá-lo, que ele estaria ali, continuaria ali, como estava (VILELA, 2016, p. 23-24).

O narrador, embora não conheça a origem do paradoxal buraco, que tanto lhe produz encantamento como assombro, sabe da existência deste e da impossibilidade de desvinculá-lo de seu próprio ser. Desse modo, o buraco transcende o quintal e passa a existir na interioridade do narrador, a compor sua identidade. Durante a adolescência, o protagonista tenta ignorar a existência do buraco em seu quintal, levando uma vida social ativa e permanecendo rodeado de pessoas. Todavia, ao se ver um pouco isolado e em silêncio, pressente o surgimento dele em seu interior, "[...] como uma serpente se erguendo no escuro" (VILELA, 2016, p.24). Por outro lado, há momentos em que o narrador deseja relembrar a existência do buraco, "[...] como um último socorro, e então ficava contente por ele existir" (p.24). A reminiscência do buraco torna-se tão intensa que, mesmo sendo constituída pela ausência do referente, apaga "[...] a presença das pessoas - como se elas, então, é que se tornassem lembrança" (p.24). Por meio dessa estratégia descritiva antitética, o narrador, ao relativizar os conceitos comumente aceitos de "referente", "presença" e "ausência", convoca seu leitor implícito a uma reflexão metalinguística em que se problematiza a capacidade da linguagem de conter e conferir um sentido consensual à existência.

O fantástico consolida-se na fatura narrativa, por meio da proliferação de fatos insólitos que se aproximam aos poucos do surreal, o buraco metaforiza os sentimentos contraditórios vividos na adolescência do herói, os fantasmas, as incertezas. Através de um relato intimista, o protagonista não consegue mais evitá-lo: "Ignorá-lo foi o que tentei de vez em quando nesses anos de adolescência" (VILELA, 2016, p.24). As descrições do narrador referentes ao buraco - ora de efeito maléfico, assemelhando-se a uma víbora, pois o envenena e provoca-lhe sofrimento: "Isso me deixava tão desconsolado, que eu tinha vontade de morrer" (VILELA, 2016, p.24); ora semelhante a um 
auxílio, apoio, refúgio; ora como dominador, pois ocupa sua mente -, não deixam "espaço" para outras existências. Pelo paradoxo, o protagonista revela-o como incognoscível.

Essas descrições, aliás, complexificam esse local, instaurando estranhamentos e lacunas no relato, os quais podem convocar o leitor a constantes revisões de hipóteses. O paradoxo permanece, ainda, na descrição desse buraco que, embora constituído pelo vazio, avança para a existência do narrador, adentrando-o. Nesse processo, o buraco passa a constituir sua identidade, determinando suas variações de humor ao logo do dia - alegria, incerteza e tristeza. Por constituí-lo, o buraco revela as atitudes díspares do narrador, marcadas pela definição antitética de alguém cuja essência é, paradoxalmente, preenchida pela ausência.

Cabe, então, ao leitor mergulhar, ao lado desse intrigante protagonista, no vazio da incerteza, em um buraco insólito, surreal. Como assinala Anatol Rosenfeld (2000, p.45), algumas personagens "[...] muitas vezes debatem-se com a necessidade de decidir-se em face da colisão de valores, passam por terríveis conflitos e enfrentam situações limite [...]". Provavelmente por isto, essas personagens em estado de tensão permanente, como o protagonista do conto de Vilela, podem ser cativantes para o jovem leitor, pois como são enigmáticas, suscitam seu desvendamento durante toda leitura, ativando sua produtividade advinda da utilização de sua capacidade imaginativa e interpretativa. Para Iser (1999), só por meio dela, a leitura torna-se prazerosa.

A tensão se estabelece na narrativa de forma gradual e crescente, assim como o buraco. Intensificase no conto fantástico a hesitação de um narrador frágil, impotente diante de algo aterrorizante que, à medida que se amplia o abarca, ao mesmo tempo que é adentrado por ele. O protagonista, ao cavar seu buraco, adentra um duplo subterrâneo: o do espaço de seu quintal e o de sua alma. Nota-se um movimento paradoxal na trama, pois o herói adentra o buraco, enquanto este amplia-se no seu âmago. O efeito impactante decorre da forma, ou seja, da simplicidade de vocabulário e de sintaxe nas complexas descrições desse mergulho duplo pelos subterrâneos. Para Carneiro é desse perscrutar da alma humana que Vilela retira "[...] o barro com que molda suas histórias" (2005, p.125). Embora a linguagem no conto seja coloquial e aparentemente despretensiosa, suas cenas são construídas de forma cada vez mais tensa, como se pode ver no fragmento:

Houve ocasiões em que eu escondia dos outros o buraco, numa espécie de medo ou de pudor. Ou, se me sentia muito triste por ele existir, mostrava-o para eles, na esperança de que dissessem ou fizessem alguma coisa para diminuir minha tristeza. Uns nem ligavam, outros davam conselhos, e alguns acabaram se oferecendo para me ajudar a tapá-lo (VILELA, 2016, p.25).

Ao longo da leitura do conto, o leitor acompanha a atração do adolescente pelo buraco que, por não conseguir mais se reconciliar com os outros nem consigo, o adentra como forma de fuga e escapismo. Tal opção apresenta-se verossímil dentro da construção do texto pelo viés do insólito, do inexplicável. Aos poucos, a imprevisibilidade dos fatos aumenta, há um desmantelamento gradativo da identidade do narrador que passa a morar em um espaço precário - frio e úmido - com naturalidade: "Depois de alguns minutos, a sensação de pavor havia desaparecido por completo, e eu, ali, sentia-me bem, perfeitamente à vontade, como se ali fosse realmente o meu lugar, o meu habitat" (VILELA, 2016, p.27).

No encaminhamento da história, algo mais desconcertante, que beira o patético e o risível, vem à tona no diálogo do protagonista com uma das pessoas que o cercam: "Você está parecendo tatu, me disse uma dessas pessoas. Tatu é que fica cavando buraco assim. Desse jeito, um dia, quando você menos esperar, você está aí virado num tatu. Olha suas mãos sujas de terra" (VILELA, 2016, p.28). Essa cena põe em relevo a situação surpreendente em que se encontra o protagonista. Esse efeito é obtido pela situação antitética em que se trata de algo complexo a inadequação social do protagonista -, de forma jocosa, por meio de um diálogo coloquial e descontraído.

Em momento posterior a essa cena, o protagonista se mostra predisposto a deixar o espaço 
coletivo para se enfiar de vez no buraco: "Tatu, eu pensei... e se eu virasse mesmo um tatu? Aquelas pessoas me deixariam em paz no meu buraco, não viriam molestar-me" (VILELA, 2016, p.28). Por meio da elipse ("Tatu, eu pensei...") marcada pela vírgula e do emprego das reticências, o texto produz vazios que sugerem uma profunda reflexão do protagonista para sua tomada de decisão por habitar o buraco, revelando a cisão homem/mundo, como forma de ingresso à esfera do sujeito. As lacunas sugerem, no conto, o isolamento permeado pelas manifestações conscientes e inconscientes do protagonista de angústia, enfim, de inadequação social. Elas se configuram como alegoria da alma dele, marcada pelo vazio existencial. Para Claudine Haroche, a elipse pode ser associada a refúgios onde a liberdade do sujeito pode se expressar, ou seja, "[...] zonas de obscuridade e de ambiguidade necessárias à liberdade" (1992, p.116). De fato, no alegórico buraco, composto pela ausência de matéria e símile de elipse, cria-se um refúgio, onde a personagem pode exercer sua liberdade de subversão à ordem social.

No decorrer da trama, o leitor pode notar que as situações insólitas acentuam-se, pois o buraco tornase tão profundo que as pessoas não veem mais o protagonista em seu interior. Além disso, ele elege a incomunicabilidade quando elas se aproximam da sua beirada e o interpelam:

Acontecia, às vezes, de chegar gente me procurando; curvavam-se sobre o buraco, mas ele já estava muito fundo para que pudéssemos enxergar alguma coisa. Então gritavam: "Zé, você está aí?" Eu não respondia. "Zé, ô Zé; sou eu, Maria". Maria era a minha noiva. Eu não respondia, mesmo sendo ela. Então havia um silêncio, que eu percebia ser o da pessoa esperando ainda que chegasse lá em cima algum som de baixo; mas eu ficava bem quieto. Então o silêncio voltava a ser o de antes: a pessoa tinha ido embora (VILELA, 2016, p.29).

O mutismo do personagem-narrador, Zé, impõe o silêncio ao outro. Essa estratégia leva-o à "leitura" da ausência. Ele passa a interpretar as diferentes formas de "silêncio" das pessoas de seu convívio: ora elas esperam por resposta, ora desistem desta, por terem percebido que o protagonista não quer se comunicar.
Vale destacar que seu nome só é revelado pela noiva, ainda assim, na forma abreviada. Em momento algum do conto, a mãe o chama pelo nome, mencionando apenas o termo "filho" associado ao possessivo "meu". Essa estratégia do escritor de caracterização das personagens, como sujeitos absolutamente comuns Zé e Maria -, confere ao texto a aparente sensação de tratar de um fato corriqueiro. Contrariamente, o desenrolar das peripécias rompe com essa hipótese, acentuando o estranhamento pelo instaurar do insólito em espaço e contextos mundanos.

Sua mãe tenta dissuadi-lo da intenção de permanecer no buraco, utilizando-se de chantagem emocional:

Minha mãe um dia disse: "Meu filho, você não está exagerando? [...] Um dia desses eu vinha na rua, quando ouvi, atrás de mim, uma moça dizendo a outra: 'Aquela ali é a mãe do tatu...' Você acha que isso é uma coisa agradável de uma mãe ouvir? Você é meu filho, não quero que te chamem de tatu, você não é tatu, você é gente, não é tatu" - e ela disparou a chorar. Tive tanta pena dela esse dia, que eu prometi não voltar mais ao buraco (VILELA, 2016, p.30).

Contudo, fora do espaço constituído pelo buraco, o narrador sente-se desambientado, adoecido, a luz e os sons o incomodam, e o sol queima seus olhos. A tensão atinge seu ponto máximo quando, conforme as descrições do narrador, concretizam-se em seu corpo as pilhérias que ele ouve nas ruas. Assim, pelo constante cavar, ele se metamorfoseia, adquire uma corcunda e seu rosto vai se afinando e escurecendo, além disso, ele anda somente com as mãos nos bolsos, pois já não lembravam "[...] mãos humanas: eram negras, grossas, compridinhas e com unhas fortes e pontudas - eram mãos de tatu" (VILELA, 2016, p.31). Essa elevada tensão também aparece nas suas atitudes em casa, pois Zé, deprimido e sem perceber, começa a se locomover de quatro: "Mamãe deu um grito, e só aí eu percebi a coisa" (p.31). Pode-se notar, então, que a mãe horroriza-se com o absurdo das atitudes do filho.

Nas entrelinhas da fala da mãe e nas suas atitudes, o leitor pode depreender o perfil psicológico do protagonista. A anormalidade e o insólito em face 
de um acontecimento aparentemente sobrenatural ganham relevo, por meio de uma linguagem direta, informal, que se torna impactante. À medida que o texto avança, a imprecisão dos fatos vai sendo aumentada. O que no início parecia absurdo - o narrador se "transformar" em tatu - soa natural dentro da verossimilhança do texto.

No início da história, o protagonista vive em dois espaços, um coletivo, o da rua; e um particular, o buraco, espaço insólito que provoca no leitor, segundo Todorov (1981), percepção ambígua dos acontecimentos narrados. Ou seja, o leitor começa a notar que se trata de uma narrativa imprevisível:

Nos dias seguintes, mamãe e ela [Maria], e depois meus amigos mais chegados, sempre vinham ao buraco e diziam toda espécie de coisas para me tirar dele. Mas era inútil. Fazer, eles não podiam fazer nada. Se quisessem, por exemplo, alargar até o fundo o buraco com máquinas - o que seria um serviço monstruoso - para que pudessem me pegar, seria trabalho perdido, porque eu poderia em pouco tempo furar outro buraco e penetrar pela terra em outra direção [...] tanto trabalho para pegar um tatu? (VILELA, 2016, p.35)

A partir dessa cena não existe mais limite espacial definido, o espaço é totalmente móvel, lúdico, um lugar de difícil acesso, porque o mundo para o protagonista é incompreensível. Sob essa perspectiva, ele pode se arriscar em novas aventuras, mover-se em direções várias e escapar por túneis diversos. Todas as perspectivas se abrem na medida em que 0 narrador direciona o olhar do leitor para uma figuração espacial sombria, subterrânea, insólita.

O que a princípio causa estranheza - o comportamento de um jovem que se assemelha a um tatu - torna-se aceitável, como se fosse algo banal, corriqueiro. No decorrer do texto, fica evidente a impossibilidade do protagonista de retorno à origem (superfície), de regresso ao que ele era antes: "Depois que as pessoas deixaram de vir, comecei a sentir muito a falta de uma coisa que eu não sabia o que era, mas então descobri: a voz humana" (VILELA, 2016, p.36). Nota-se, pelo relato, que o protagonista pode sair do buraco a qualquer momento e se esgueirar, à noite, pela área lateral da casa, ouvindo os sons que veem dela. Embora sinta saudade da voz humana e do convívio: "E não era mais só a voz que me encantava: era tudo o que diziam, mesmo coisinhas como "hoje está quente", "o cafezinho está gostoso", "amanhã tem feira"..." (p.37), o narrador percebe que não pertence mais a esse mundo, pois se reinserido em seus espaços, "[...] cansaço e desgosto são o que eu sentiria - e talvez sentisse também saudades do tempo em que eu era tatu" (p.37).

Como se pode notar ao longo da leitura do texto, a inadequação do protagonista é encenada por meio de uma linguagem direta, em alguns momentos por meio de um humor sutil. Ao término do conto, ao invés de um gran finale, vem à tona, no último parágrafo, o humor corrosivo:

Foi numa dessas noites que eu fiquei sabendo por que Maria não voltava mais: ela havia ficado noiva de um tal João não sei do quê. Quando ouvi isso, senti uma pontada no coração e uma enorme tristeza. Mas logo voltei a mim e pensei: "Diabo, o que eu quero? Por acaso queria que ela continuasse minha noiva?" Acabei achando a ideia divertida, e pensei numa manchete de jornal assim: "Mulher, apaixonada por um tatu, mata-se." Seria engraçado... (VILELA, 2016, p.38).

A irreverência, por sua vez, não ameniza a tensão. $O$ conto não expressa complacência com seu leitor implícito, justamente por isso, rompe com seus conceitos sobre narrador coerente, enredo pautado por causalidade e consequência, por finais "felizes" e/ou por soluções para os conflitos do protagonista. Desse modo, não se pode ignorar que a linguagem do conto, aparentemente despretensiosa e irreverente em alguns momentos, exprime uma experiência traumática: a da inadequação e incomunicabilidade social. Como alegoria da subjetividade do protagonista, essa linguagem é marcada por paradoxos, elipses, reticências, ausências de definições, revelando para o leitor em formação que a representação literária em sua realização também pode expressar o silêncio e até mesmo a incapacidade de um indivíduo de se comunicar.

O humor irreverente manifesta não só a decepção do personagem central - "[...] uma pontada no coração" (VILELA, 2016, p.38) -, mas sua busca pela cumplicidade com o leitor visado, manifesta nas reticências. Por meio delas, abre-se um vazio para que 
as afirmações do narrador ganhem concretude na comunicabilidade com o outro, por meio de seu imaginário. Aliás, esse "outro" - leitor implícito - é o único com quem o narrador consegue se comunicar, mesmo assim, esse diálogo não se efetiva, pois é só projetado no texto.

O conto, ao forçar os limites de seu gênero, assim como o romance de tensão transfigurada (BOSI, 1985), toca nos gêneros poesia (alegoria) e tragédia, permitindo ao leitor relativizar também as classificações que se atribuem aos textos literários. No final da narrativa, prevalece a opção da personagem por permanecer no buraco. Enfatiza-se, assim, mais uma vez a opção pelo insólito, pelo fantástico, como forma de rejeição a uma literatura essencialmente realista.

\section{Considerações finais}

Pela análise do conto "O Buraco", de Luiz Vilela (2016, p.19-38), pode-se observar que o leitor implícito, que se projeta na estrutura de apelo do texto, é inteligente. Esse leitor, pela relativização no enredo de conceitos como "presença" e "ausência", é convocado a refletir sobre a complexidade existencial e a pôr em suspenso a crença social de que o entorno, as coisas e os comportamentos podem ser plenamente definidos, descritos e, em especial, explicados. Nesse sentido, o conto pode romper com os conceitos prévios do leitor em formação, fomentando seu senso crítico e permitindo-lhe ampliar seus horizontes de expectativa.

Sua temática da individuação, aliada à denúncia de realidades sociais opressivas, é própria da narrativa contemporânea, conforme Karl E. SchØllhammer (2009). Justifica-se, então, a validade de nossa hipótese de que esse conto tem potencial para emancipar o jovem leitor, pois este reflete de forma crítica sobre os pressupostos da realidade e da construção de identidades definitivas e coerentes. Essa temática associada à profundidade filosófica representa o sujeito mutilado pela incapacidade de se expressar de forma autêntica com as pessoas de seu convívio. Além disso, problematiza a sua incapacidade de captar pelos sentidos a realidade. Nessa impossibilidade acentua-se a ausência de sentido nas relações humanas que confere ao conto o teor de crítica aguda à sociedade.

Por meio da contextualização do conto, pode-se notar ainda a crítica social, pois o texto é publicado em um cenário marcado por silenciamentos, ausência de liberdade de expressão e paradoxos. Nesse contexto, o único diálogo possível surge na arte, na literatura, mais especificamente, em um conto em que, por meio de "buracos" - vazios, elipses, ambiguidades, paradoxos, potências de negação e reticências -, busca estabelecer comunicabilidade com um leitor implícito inscrito no texto. Essa comunicabilidade inscrita no texto, uma vez descoberta pelo jovem leitor, pode assegurar-Ihe o prazer, pois se sente considerado pelo relato durante a leitura.

"O buraco" (VILELA, 2016, p.19-38) pode ser aproximado dos romances de tensão transfigurada, pois seu protagonista, com a finalidade de superar o conflito existencial que o constitui, metamorfoseia-se em tatu, decidindo viver em uma profunda cratera que produziu ao longo de sua vida e na qual nenhuma pessoa de seu convívio consegue adentrar. Vale destacar que, uma vez no centro desse espaço, ele não pode ser visto pelos que se aproximam de sua beirada. Embora ele os veja e ouça, permanece oculto, encoberto por suas sombras. Além disso, com a competência adquirida pela metamorfose, ele pode se mover por outros túneis e ver o que acontece no seu entorno, sem ser visto. O herói, ao se desumanizar, paradoxalmente adquire um direito próprio do ser humano: o de livre arbítrio.

Nesse sentido, o "buraco" - produto da escavação do narrador, mas também centro de sua alma - torna-se alegoria da existência humana, marcada por ausências e carências de ordens diversas. No espaço marcado pelo vazio - o buraco -, refugia-se o protagonista do convívio social. Como ele não se adequa ao mundo em que vive, constrói outro para si. Contudo, mesmo fora desse espaço, afirma que o buraco o constitui, está dentro dele, revelando que está condenado ao mergulho nos subterrâneos tanto no espaço externo, quanto interno: em sua subjetividade. O personagem encontra-se, assim, em 
espaços marcados pela ausência e pela presença da solidão e incomunicabilidade. Resta-lhe para sobreviver a esse contexto aceitar o processo de animalização, desumanização.

Para o leitor em formação, as ambiguidades e os paradoxos, bem como o efeito de estranhamento, resultante do choque entre linguagem e espaço mundanos, associados ao insólito, e do relato ulterior de um narrador autodiegético inseguro, tanto podem despertar sua curiosidade, quanto suscitar constante atividade imaginativa em busca de concretude (ISER, 1999). Além disso, pela leitura do conto, o leitor é impelido à revisão de conceitos prévios associados ao uso da linguagem e aos elementos estruturais que compõem uma narrativa.

Segundo Iser (1999), a leitura só se torna um prazer no momento em que a produtividade do leitor implícito entra em jogo, ou seja, quando os textos lhe oferecem a possibilidade de exercer a sua capacidade. Entretanto, há limites de tolerância para essa produtividade que são ultrapassados quando o autor diz tudo claramente ao leitor ou quando o sentido do que está sendo dito ameaça dissolver-se e tornar-se difuso. Nesse caso, o tédio e a fadiga representam situações-limite, indicando, em princípio, o fim da participação do leitor. Pela análise do conto de Vilela (2016, p.19-38), pode-se deduzir que o grau de exigência da produtividade do leitor, embora seja constante e aumente gradativamente, não impede sua participação. Pelo contrário, o aumento da tensão, associado ao insólito, pode capturá-lo e mantê-lo fiel ao relato até o seu desfecho, promovendo o efeito de prazer na leitura.

No conto "O buraco" (VILELA, 2016, p.19-38), a relação entre leitor implícito e obra é dialógica, por isso pode ser entendida, de acordo com Jauss (1994), tanto como a da comunicação com um provável receptor, quanto a relação de pergunta e resposta embasada no âmbito de uma história da literatura e no nexo entre as obras literárias. Mesmo que ao leitor contemporâneo pela ausência de mediação, embora a obra esteja inserida em acervos do PNBE -, escape o contexto histórico de produção do conto, bem como sua dialogia com outras narrativas fantásticas, em especial, $\operatorname{com} A$ metamorfose, de Franz Kafka, pela transformação do protagonista, pelas suas temáticas de individuação, inadequação social, livre arbítrio e cisão entre sujeito e mundo, o texto demonstra sua atualidade e vitalidade, sendo-Ihe atraente e despertando seu senso crítico sobre as relações humanas em sociedade.

Desse modo, o conto possui potencialidades para se converter num meio de cultura e questionamento, conferindo, assim, relevo à função social da leitura. O desenvolvimento dessa função, por sua vez, pode incrementar no leitor a capacidade de investigação crítica sobre o que promove a leitura de determinadas obras, se é o seu valor estético e a comunicabilidade que estabelece com seu leitor implícito ou, somente, sua inserção em estratégias mercadológicas promovidas por oligopólios. Em síntese, o conto "O Buraco" (VILELA, 2016, p.19-38), ao propor a reflexão crítica, rompe com os conceitos prévios do leitor habituado a textos provenientes da cultura de massa, em geral, filiados ao entretenimento.

\section{Referências}

BOSI, A. História concisa da literatura brasileira. 3.ed. 9.tir. São Paulo: Cultrix, 1985.

BOSI, A. O conto brasileiro contemporâneo. 22.ed. São Paulo: Cultrix, 2008.

CARNEIRO, F. No país do presente: ficção brasileira no início do século XXI. Rio de Janeiro, Rocco, 2005.

FERNANDES, C. R. D. A seleção de obras literárias para o Programa Nacional Biblioteca da Escola PNBE 2006-2014. Disponível em: $<$ http://www.scielo.br/pdf/elbc/n51/2316-4018-elbc51-00221.pdf>. Acesso em: 20 fev. 2019.

FNLIJ. Disponível em: <http://fnlij.org.br/imagens/arquivos/catalogos\%20 bolonha/bolonha_2010.pdf>. Acesso em: 21 ago. 2019.

GAMA-KHALIL, M. M. A literatura fantástica: gênero ou modo? In: Terra Roxa e outras terras - Revista de Estudos Literários, Londrina/PR, v.26, p.18-31, dez. 2013.

HAROCHE, C. Fazer dizer, querer dizer. Trad. Eni P. Orlandi. São Paulo: Hucitec, 1992.

ISER, W. O ato da leitura: uma teoria do efeito estético. Trad. Johannes Kretschmer. São Paulo: Ed. 34, 1999. vol. 2. 
ISER, W. O ato da leitura: uma teoria do efeito estético. Trad. Johannes Kretschmer. São Paulo: Ed. 34, 1996. vol.1.

JAUSS, H. R. A história da literatura como provocação à teoria literária. Trad. Sérgio Tellaroli. São Paulo: Ática, 1994.

MORICONI, Í. (org.). Os cem melhores contos brasileiros do século. Rio de Janeiro: Objetiva, 2001.

ORTIZ, R. A moderna tradição brasileira: cultura brasileira e indústria cultural. 5. ed. 4. reimpr. São Paulo: Brasiliense, 2001.

PINTO, M. de O. O insólito, os autores, e a crítica literária: perspectivas no sistema literário brasileiro. In: _ ; GARCÍA, F.; MICHELLI, R. (orgs.). Vertentes do fantástico no Brasil: tendências da ficção e da crítica. Rio de Janeiro: Dialogarts, 2015, p.159-172.

PORTAL MEC. Disponível em: <http://portal.mec.gov.br/index.php?option=com_d ocman\&view=download\&alias=13914-pnbe-2011seb-pdf\&category_slug=agosto-2013pdf\&ltemid=30192>. Acesso em: 08 fev. 2018.
ROAS, D. A ameaça do fantástico: aproximações teóricas. Trad. Julián Fuks. São Paulo: Unesp, 2014.

ROSENFELD, A. Literatura e Personagem. In: CANDIDO, Antonio et al. A personagem de ficção. 10.ed. São Paulo: Perspectiva, 2000, p.9-49.

SCHØLLHAMMER, K. E. Ficção brasileira contemporânea. Rio de Janeiro: Civilização Brasileira, 2009.

STALLONI, Y. Os gêneros literários: narrativa, teatro e poesia. Trad. Claudete Soares. Portugal: EuropaAmérica, 2010.

TODOROV, T. Introdução à literatura fantástica. Trad. Maria Clara Correa Castello. São Paulo: Perspectiva, 1981.

VILELA, L. O buraco. In: Três histórias fantásticas. 2.ed. São Paulo: SESI-SP editora, 2016, p. 19-38.

VOLOBUEF, K. Uma leitura do fantástico: $A$ invenção de Morel (A. B. Casres) e O processo (F. Kafka). In: Revista Letras, Curitiba/PR, n.53, p.109-123, jan./jun. 2000. Editora da UFPR.

\section{COMO CITAR ESSE ARTIGO}

FERREIRA, Eliane Aparecida Galvão Ribeiro; BULHÕES, Ricardo Magalhães. O conto fantástico na formação do leitor: uma leitura do conto "O Buraco", de Luiz Vilela. Signo, Santa Cruz do Sul, v. 45, n. 82, jan. 2020. ISSN 1982-2014. Disponível em: <https://online.unisc.br/seer/index.php/signo/article/view/14268>. Acesso em: doi:https://doi.org/10.17058/signo.v45i82.14268. 